\title{
Statistical Analysis of Performance Indicators of the Leading Russian Exporters
}

\author{
Mariia Gorbunova $^{1}$, Mariya Khazan ${ }^{1}$, Elena Livanova ${ }^{1} \&$ Tatiana Morozova $^{1}$ \\ ${ }^{1}$ International Economics and Customs Affairs, Institute of Economics and Entrepreneurship, Lobachevsky State \\ University of Nizhny Novgorod - National Research University, Nizhny Novgorod, Russian Federation
}

Correspondence: Mariia Gorbunova, International Economics and Customs Affairs, Institute of Economics and Entrepreneurship, Lobachevsky State University of Nizhny Novgorod - National Research University, Nizhny Novgorod, 603950, Russian Federation. Tel: 7-831-430-3843. E-mail: gorbunova@ iee.unn.ru

Received: August 25, 2020

Accepted: November 5, 2020

Online Published: January 3, 2021

doi:10.5430/rwe.v12n1p68

URL: https://doi.org/10.5430/rwe.v12n1p68

\begin{abstract}
Promoting the country's competitiveness amid global turbulence is an important task at every level of the economy's management. In the circumstances of Russia's shrinking trade balance, which is due to the unfavorable resource market environment, studying the businesses of Russian exporters becomes a relevant research problem. The focus is placed on the dilemma of commodity/non-commodity exports, which is important to emerging markets.

During the research, the authors conducted an analysis of revenue indicators and commodity and geographical diversification indicators of the leading Russian exporters based on materials from Expert Business Weekly, which may yield the following conclusions. First, resource companies' export revenues are less volatile. Second, research results confirm, in a direct or an indirect way, the greater inclination and efficiency of resource exporters towards geographical (country-wise) diversification, whereas commodity diversification is an export strategy tool of non-resource companies. Third, the authors identified a positive correlation between foreign trade revenues, on the one hand, and the number of countries served and trade items offered, on the other hand, for mineral and energy companies; moreover, a higher elasticity of export revenue on a number of markets served was revealed. For the manufacturing exporters representing chemical, petrochemical, and food industries, a positive correlation between export revenues and the number of HS 4-digit commodity lines was identified in some years and industries alongside a higher elasticity of export income on number of commodity lines. The linear regression model showed that the addition of a new product in terms of HS 4-digit code would lead to a bigger increase in export income than a new national market entry. So, the authorities should support a product diversification of both commodity and manufacturing exporters encouraging the innovation.
\end{abstract}

Thus, the performed analysis is of great practical importance, since Russia is the largest trading country in Central Europe. And the results shed light on export performance of its leading companies.

Keywords: rating of exporters, resource export, non-resource export, business diversification, commodity and geographical diversification, theory of heterogeneous exporters

\section{JEL codes: F14, F23, M16}

\section{Introduction}

Exporters are the core of industrial potential of the national economy: They create new jobs, which are globally competitive; stimulate the inflow of foreign currency to the country; and act as leaders of progressive changes, especially if their manufacturing processes are based on factors that were developed by the country, not inherited. In present-day conditions characterized by long-term deterioration of the global business environment, mainly in the foreign resource markets important to our country, as well as the unfavorable geopolitical situation for Russian business entities, the interest is growing, from the point of systematization of experience and development of strategic recommendations for the foreign trade participants, power authorities, and non-public export-supporting organizations, in empirical synthesis of the business experience of Russian enterprises selling their products abroad.

The problems of Russian exports are aggravated by their resource-oriented nature. The deterioration of the trade environment due to dropping resource prices leads to the growth of tension because of the necessity of exporting 
more commodities in physical volume. Therefore, the key challenge of foreign trade is the promotion of non-resource commodities in foreign markets, which will further strengthen Russia's strong positions in the machine-building (first, nuclear power engineering and defense mechanical engineering), chemical, and food industries. In the context of significant industry competition, the experience of the leading companies, in our opinion, is not only of interest to the researchers but also has a high degree of representativeness. The authors believe that commodity and geographical diversification is the most prospective area to research foreign economic relations because of (1) the commitment to phase out imports proclaimed by the Russian Government, which is aimed at improvement of the country's trade balance; (2) the unfavorable situation in the resource markets; and (3) the deterioration in relations with traditional trade and investment partners. The need to diversify Russian exports in terms of growth of the share of high-tech industries was also declared a high-priority challenge in the "Foreign Economic Strategy of the Russian Federation 2020" (Pravitel'stvo Rossijskoj Federacii, 2008). The latest "Major Areas of Government Activities 2024" also rely on the strategy of export-oriented growth of the national economy, primarily due to non-resource companies selling their products abroad (Medvedev, 2018).

Therefore, the aim of this research is to synthesize and make a descriptive analysis of a number of performance indicators for Russian exporters, which are shown in the rating of Expert Business Weekly (2015), which synthesizes the data of 2013-2014, within the frame of which, apart from industry and regional aspects, special attention is paid to the commodity and geographical diversification of sales abroad by 162 resource and 85 non-resource exporters. To achieve this aim, the authors propose, first of all, to group the indicators available and, second, to investigate the interconnection of commodity and geographical diversification indicators available for the assessment of enterprise revenues, taking into account the resource or non-resource nature of their business, as well as the industry they belong to.

Moreover, the analysis of data from the open rating of exporting enterprises, in contrast to studying and modeling disguised business indicators, makes it possible to evaluate the strategic and operational context of internalization of the country's leading companies.

The scientific novelty of this research is due to the fact that, first of all, its object is a rather large selection of the country's largest exporters, using data collected by Expert Business Weekly within the frame of subject rating, which have been introduced into the scientific discourse by the authors. Second, the nature of the data made it possible for the authors to enter an idea on the different importance of geographical and commodity diversification to resource and non-resource exporters.

\section{Literature Review}

\subsection{Russian Business Commodity and Geographical Diversification and Internationalization Issues}

These days, there are several areas in our country of studying foreign trade, foreign investments, and other aspects of Russian business internationalization in the post-Soviet era.

A significant block of studies of domestic enterprises taking part in global value chains focuses on the largest Russian corporations (joint-stock companies), which are the business entities most open as regards information disclosure; a telling example is a monograph by Panibratov revealing a broad range of problems of the Russian TNC genesis (Panibratov, 2012). A significant number of works analyze the strategic aspects of Russian corporations' operation in foreign markets. A quantitative empirical study by Panibratov et al. (2015) was devoted to the analysis of dynamics and assessment of the impact of different types of distance on the direct foreign investments of the Russian leading companies, while the works of Panibratov (2010) and Katkalo and Medvedev (2011), within the frame of the case study, investigated the configuration (forms of market entry and further operations) of Russian corporations' foreign activities.

Kuznetsov $(2010,2011,2016)$ in his studies synthesized Russian corporations' reporting data on the foreign projects they implemented while uniting the micro- and macro-levels of the investment process and creating an empirical view on domestic capital investments abroad as regards dynamics and industrial and geographical distribution. Current geopolitical processes, which have a negative effect on Russia's global positioning and affect the investment risks of its business entities abroad, were reflected in his latest study, which focused on the assessment of the diversification potential of Russia's foreign investments through investments in African and Asian countries (Kuznetsov, 2017).

The non-corporate sector of the Russian economy and its export operations have mainly been researched in the works of Yudanov (2010) and the periodic analytical reviews of Expert Business Weekly (Expert, 2015), which are based on a database of joint research on gazelle companies (fast-growing medium-sized companies of the 
non-resource sector) by the Financial University under the Government of the Russian Federation and Expert Media Holding. This group of studies makes it possible to evaluate such qualitative operating indicators of this group of companies as their strategic orientation, the types and sources of their competitive advantages, and their factors for choosing foreign commodity and geographical markets, as well as to better understand the problems facing gazelle companies in the course of internationalization.

The vital problem of export diversification is mainly studied at the macroeconomic level, broken down by commodity groups and importing countries, mainly using the statistics from the UN Comrade Database and the Federal Customs System of Russia. Gnidchenko (2014) synthesized several methods of assessing export potential based on the latest foreign approaches and identified considerable growth perspectives of industrial machine-building and chemical industry complexes relying on other competitive advantages of the country at an international level.

Piskulova (2015), in the course of an analysis of the commodity and geographical structure of the Russian Federation's external trade, came to the conclusion that the insufficient level of geographical diversification of Russian exports is caused by the country's resource orientation, which is, in fact, low commodity diversification.

Shurygin's (2017) analytical work published in Expert Business Weekly, brought up to date the topic of development of Russian non-resource (manufacturing) exports; the author identified 28 six-digit commodity items (with a turnover in the interval from USD 2.43 billion to 2.5 million) of which the Russian Federation is the world's largest exporter, of which four commodity items belong to food products and agricultural raw materials (at USD 728.4 million); one to fuel sector (USD 596 million); eight to chemical industry and rubber (USD 1,862.7 million); zero to timber and pulp-and-paper products; 10 to metals and metal products (USD 2,514.2 million); two to machines, equipment and vehicles (USD 860.9 million); and four to no large commodity groups (natural ground calcium phosphates; asbestos, cement asbestos products; untrimmed fur pelts: USD 473.9 million).

Spartak and Khokhlov's (2016) study, which directly focused on diversification, discussed the growth of commodity diversification due to the 2013-2015 increase of a number of six-digit commodity items in the country's exports and the extension of export geography for many commodity items. In the researchers' opinion, prospective regions for the Russian export included the countries of Sub-Saharan Africa and the Asia-Pacific, while the exports to the countries of the European Union, North Africa, and North America, including also the trader and offshore countries, such as Switzerland, Cyprus, and the Virgin Islands, were declining. A team of researchers, including Andreyeva et al. (2017), based on the example of Sverdlovsk Region, also confirmed the growing importance of the Eurasian Economic Union, BRIC(S), and Shanghai Cooperation Organization countries, as well as other developing countries of Asia, in the development of non-resource exports for this industrial region, which stimulates production of higher-conversion products and economic diversification.

A number of studies of export diversification are related to the analysis of regional specialization and clusterization. The work of Yevchenko and Gubanov (2013) made conclusions not only about the resource nature of exports, which is unfavorable for the economy as a whole, but also about the growth of monoproduction, which means the presence in the structure of export supplies of the federation's subjects and federal regions of commodity HS of two-digit aggregates with a share of over 50\%, with the following breakdown of data distributed by Rosstat: food products and agricultural raw materials (groups 1-24); fuel and energy sector products (group 27); chemical industry products and rubber (groups 28-40); timber and pulp-and-paper products (groups 44-49); metals and metal products (groups 7283); and machines, equipment, and vehicles (groups 84-90). This trend is a telling one, but it is not clearly negative, since it may be a consequence of positive effects related to the formation of export-oriented regional clusters, which are globally competitive.

It is worth paying attention to some works of Kadochnikov and Fedyunina, which were dedicated to the analysis of the prospective structure - in a certain way, the diversification - of the regions' exports, which was based on the analysis of microdata arrays shown in the general population of commodity declarations of foreign trade operators, which are processed by the Federal Customs Service. Thus, Kadochnikov and Fedyunina's (2013) research revealed that well-to-do regions are characterized by export growth due to intensive factors (with retained export specialization), while development due to new markets and commodity items is characteristic of the regions with worse economic indicators, which stresses their unstable growth. Therefore, diversification is viewed here as a phenomenon that is controversial for business. In a later work of 2015, the previously mentioned team of researchers (Kadochnikov \& Fedyunina, 2015) revealed five clusters of non-resource industries that have large potential to extend their exports:

- Manufacture of electrotechnical equipment and mechanisms; 
- Manufacture and processing of ferrous metals;

- Manufacture of products of chemical and related industries, including plastic materials, rubber, and rubber items, as well as manufacture of other chemical products;

- Manufacture of optical, measuring, medical, and other instruments and devices;

- Manufacture of inorganic and organic chemistry products, including manufacture of metal oxides, hydroxides, and peroxides; mineral salts; as well as alcohols, phenols, and their derivatives.

At the micro-level, the latest studies include, first, the work of Kadochnikov and Fedyunina (2017) on the impact of the external effects of foreign direct investments on the propensity to export of small and medium-sized Russian companies in processing industries. Second, the empirical analysis of the competitiveness factors of Russian exporters that was conducted by Fedyunina and Averyanova (2018) based on data from the National Research University Higher School of Economics project "Russian Enterprises in the Global Economy" for the enterprises in the processing industry in Russia in 2014 , as a result of which a positive correlation was discovered between the share of exports in revenue and the share of import purchases in variable and fixed costs. Knobel and Kuznetsov (2019), while researching Russian firms' tactics for setting export prices, discovered their dependence on the size and per capita income level of the importing country, linking this with the necessity to ensure the enhancement of product quality.

Based on analysis of works by Russian authors, one may come to the conclusion that, despite the increasing interest in resource and non-resource exports and emerging studies with high-quality mathematical modeling, Russian business entities' problems of foreign trade diversification are mainly viewed at the country level on the whole, as well as the levels of regions and industries. Besides, the works reviewed paid more attention to commodity diversification, primarily non-resource diversification, not geographical diversification, which is, most likely, determined by the research relevance of the economic task of accelerated growth of non-resource exports, which implies creation of technological jobs and innovative development. At the micro-level, the Russian scientists checked hypotheses on the factors of success and internationalization of exporters.

\subsection{Foreign Studies of Commodity and Geographical Diversification}

Firms' processes of international expansion attract foreign researchers; the identified empirical facts and laws are determined by the structure of data available to the authors. Bernard and Jensen, in their early research (1999), studied the cause-and-effect relations arising around export activities; in particular, they proved that successful and fast-growing firms will sooner become exporters, while exports stimulate the growth of employment and increase the chances of survival; however, from a long-term perspective, they will not lead to additional growth of labor productivity and salaries. According to Eaton et al. (2011), this article yielded a new generation of export theories based on the analysis of producers' heterogeneity.

Bernard et al. (2007), in the review "Firms in International Trade," once again stressed the importance of behavioral analysis of exporting firms for the development of a general theoretical basis for this type of global value chains as well as the necessity of paying attention to the competitiveness parameters of exporters as compared with the general population of firms, their differentiation when identifying strategies, and the results of their entrance into foreign markets (theory of heterogeneous exporters). Moreover, the mentioned researchers synthesized the results of empirical studies of American companies as related to the total share of exporters, the degree of their concentration, and the connection between their export and import operations.

In their recent work, Lawless et al. (2018) researched the export diversification parameters of Irish companies owned by local and foreign capital. Based on a data array covering a 20-year period, it was shown that in the short and the long term, the companies were inclined to ensure export growth due to expanding sales of earlier developed products in the markets where these companies were already present. In the long-term perspective, growth is stimulated by commodity and geography diversification in the format of market development or commodity offer renewal.

Eaton et al.'s (2011) research on exports by French firms focused not on the firms' internal characteristics but on external parameters, i.e., market parameters. As a result, it was found that entrepreneurs were more apt to export to markets whose capacities were comparable to those of the French market, while the growth of sales in the internal market correlated with sales growth in unpopular foreign markets and the number of foreign countries served.

There is no common opinion among researchers on the form of the dependence between diversification and enterprises' results; if you view a broader context of general internationalization, which includes not only foreign trade but also foreign investments, "over one hundred empirical studies of MNC operations could not yield more 
stable beliefs" (Hennart, 2007) on the problem of whether this relation between efficiency and diversification is linear, U-shaped, or S-shaped. As mentioned by Boehe and Jiménez (2016), this is because the geographical (international) diversification of businesses is most often researched chaotically-different forms of market entry and different motives are combined (market-seeking or resource-seeking), and there is confusion between diversification and the level of internationalization. In this context, business internationalization is viewed as an element of geographical diversification in relation to enterprise operations.

Therefore, studying enterprises' export diversification is deemed relevant from the viewpoint of foreign researchers; however, their hypotheses and results have largely been determined by the structure of available data on companies' exports. That is why the authors believe that analysis of indicators of the leading Russian exporters based on the 2015 rating of Expert Business Weekly, which covers the period of 2013-2014, seems to be one of few opportunities to give a quantitative assessment of foreign trade diversification at the level of individual firms and make generalizations and conclusions of not only a positive but also a normative nature to develop strategies for foreign expansion at the micro-level and programs of export diversification support at the macro-level.

\section{Research Data and Methodology}

The authors use as the research object the rating of Russia's top 200 leading exporters by Expert Business Weekly (Zhoga, 2015). This ranking contains the following indicators: enterprise name; enterprise industry; enterprise region; volume of exports to all countries (except Kazakhstan and Belarus) in 2013 and 2014, millions of USD; number of HS four-digit commodity lines exported in 2013 and 2014; and number of countries served in 2013 and 2014.

The order of enterprises in the rating corresponds to their export revenue for 2014. Besides, a similar rating was made separately for 85 non-resource exporters, 38 of which were also included in the general rating.

Methodical comments on the Expert rating. The rating tables are made based on the data of customs statistics, company reports and their target surveys. The export volume was estimated in US dollars. The content-based filter for the company selection was the company's own production capacities available; since the [rating authors] wanted to get a rating of manufacturing exporters, there are no trading and logistics companies present in the tables. However, many manufacturing companies make their export supplies via intermediaries, so they are left behind the rating (Zhoga, 2015)

The rating of the 200 leading Russian exporters goes back to the sampling of the 2015 rating analyzed by the authors. Later ratings of 2016-2018 are also interesting for researchers, but they have a different data format, which does not allow us to make a cross-cutting analysis; moreover, in 2015, the business weekly provided the most extensive list of non-resource exporters.

The introduction into scientific discourse and processing of this rating undoubtedly have interest for researchers, not only due to the availability and visibility of data but also because unlike microdata, which are disguised after processing, this rating allows us to get detailed results for the most important companies for the purpose of evaluating, for instance, their strategic decisions.

Nevertheless, the rating has several shortcomings. First, it includes no service exporters, and one can only guess which rank would have been given to the most competitive IT and logistics companies. Second, the rating was based on a voluntary survey of companies; therefore, the sampling analyzed most likely does not coincide with the general population of the leading exporters. Based on the data of other ratings by Expert Business Weekly, the list of 200 leading exporters may not include all the key representatives of foreign businesses that shape a new core of the country's international competitiveness. Third, the industry attribution of a number of companies is doubtful. For instance, Mechel and Evraz holdings represent ferrous metallurgy in the rating, whereas according to Tarazanov (2015) their coal enterprises are ranked fourth and seventh in the list of this industry's largest coal exporters.

The industry-wise distribution of enterprises from the main sampling (shown in brackets is the number of enterprises with revenue growth since 2013) is as follows: oil and oil-and-gas industries: 35 (11); wood, wood processing, and pulp-and-paper industries: 26 (19); chemical and petrochemical industries: 26 (10); machine building: 22 (12); ferrous metallurgy: 21 (15); coal industry: 18 (7); food industry: 17 (13); non-ferrous metallurgy: 11 (8); precious metals and diamond industry: 9 (2); construction materials industry: 4 (2); tobacco industry: 3 (2). One enterprise showing export growth each represents light industry, science, instrument manufacture, and transport; one enterprise showing an export decline each represents the pharmaceutical industry, machine building/science, multi-sector holding, and the electric energy sector. The sub-rating of non-resource exporters in the 2015 rating included the companies in whose export structure at least $50 \%$ of the volume comprises non-resource commodities and first-stage processing products (Zhoga, 2015). 
The regional distribution of commodity and manufacturing exporters is shown in Tables 1 and 2 .

Table 1. Region-wise distribution of 162 leading Russian commodity exporters

\begin{tabular}{|c|c|}
\hline Region & $\begin{array}{l}\text { Number of enterprises of commodity } \\
\text { exporters in the region }\end{array}$ \\
\hline Moscow (city) & 46 \\
\hline Kemerovo Region & 15 \\
\hline Saint Petersburg (city) & 14 \\
\hline Moscow Region & 8 \\
\hline Perm Krai, Samara Region, and Sverdlovsk Region & 7 \\
\hline Krasnoyarsk Krai, Leningrad Region, and Irkutsk Region & 6 \\
\hline Krasnodar Krai, Orenburg Region, and Rostov Region & 5 \\
\hline $\begin{array}{l}\text { Tatarstan Republic, Nizhny Novgorod Region, Sakhalin Region, and } \\
\text { Chelyabinsk region }\end{array}$ & 4 \\
\hline Komi Republic, Arkhangelsk Region and Volgograd Region & 3 \\
\hline $\begin{array}{l}\text { Bashkortostan Republic, Sakha (Yakutia) Republic, Khabarovsk Krai, } \\
\text { Vologda Region, Kamchatka Region, Lipetsk Region, Novgorod } \\
\text { Region, and Omsk Region }\end{array}$ & 2 \\
\hline $\begin{array}{l}\text { Buryatia Republic, Karelia Republic, Chuvashia Republic, Khakassia } \\
\text { Republic, Stavropol Krai, Amur Region, Vladimir Region, Voronezh } \\
\text { Region, Kirov Region, Novosibirsk Region, Pskov Region, Saratov } \\
\text { Region, Smolensk Region, Tomsk Region, and Yaroslavl Region }\end{array}$ & 1 \\
\hline Regions Presented in the Rating, Total & 47 \\
\hline
\end{tabular}

Source: authors based on Expert Business Weekly (2015)

Analysis of data from Tables 1 and 2 demonstrates a high concentration of the leading representatives (exporters) of Russian business in the federally governed cities, which were the place of registration of the management companies of the overwhelming majority of resource holdings, as well as non-resource public companies. The exception is the metallurgical companies of the Ural Region and Kemerovo coal enterprises. It is telling that only four representatives of non-resource exports were registered in Siberia and the Russian Far East, such as Russian Helicopters Corporation, Schlumberger Corporation, Altai Tire Combinat, and Cathode.

Table 2. Region-wise distribution of 85 leading Russian manufacturing exporters

\begin{tabular}{ll}
\hline Region & $\begin{array}{l}\text { Number of enterprises of manufacturing } \\
\text { exporters in the region }\end{array}$ \\
\hline Moscow (city) & 23 \\
\hline Saint Petersburg (city) & 11 \\
\hline Moscow Region & 10 \\
\hline Nizhny Novgorod Region & 6 \\
\hline Leningrad Region and Sverdlovsk Region & 4 \\
\hline Samara Region & 3 \\
\hline Vladimir Region, Kaliningrad Region, Rostov region, and & 2 \\
\hline
\end{tabular}


Chelyabinsk Region

Buryatia Republic, Mari El Republic, Tatarstan Republic, Altai

Krai, Perm Krai, Stavropol' Krai, Arkhangelsk Region, Belgorod

Region, Volgograd Region, Voronezh Region, Novosibirsk 1

Region, Orenburg Region, Ryazan Region, Saratov Region,

Smolensk region, and Tyumen Region

Regions Presented in the Rating, Total

28

Source: authors based on Expert Business Weekly (2015)

The industry-wise distribution of non-resource sector enterprises (shown in brackets is the number of enterprises with the revenue growth from exports in 2013-2014) is as follows: machine building: 47 (29); chemical and petrochemical industries: 9 (4); food industry: 7 (5); tobacco industry: 7 (5); instrument manufacturing: 3 (3); machine building/science: 3 (2); science: 2 (1). One enterprise showing positive dynamics each represents light industry; the pharmaceutical industry; wood, wood processing, and pulp-and-paper industries; metalworking; the construction materials industry; and the ferrous industry; the only enterprise showing a revenue drop represents the precious metals and diamond industry.

According to the calculations of Zhoga (2015), the structure of domestic exports is characterized by high concentration: around $75 \%$ of the aggregate revenue of the rated enterprises came from the export of oil, oil products, and gas, followed by ferrous metallurgy (5.2\% of aggregate export revenue), non-ferrous metallurgy (3.6\%), and chemical and petrochemical products (5\%; however, this sector is highly heterogeneous); 1-2\% came from the export of coal and coke, wood and timber, and diamonds and precious metals (which are resource exports by nature); machine building, even taking into account united production of vehicles, special vehicles, machine tools, devices, optics, and electronics, had less than $1 \%$ of the aggregate revenue of 200 leading exporters.

\section{Research Results}

Let us build the distribution diagrams for changes in export revenue, number of countries, and commodity items exported in relative expressions for 162 resource exporters out of the 200 leading exporters and 85 non-resource exporters of the Russian Federation in 2014 (Figures 1-5).

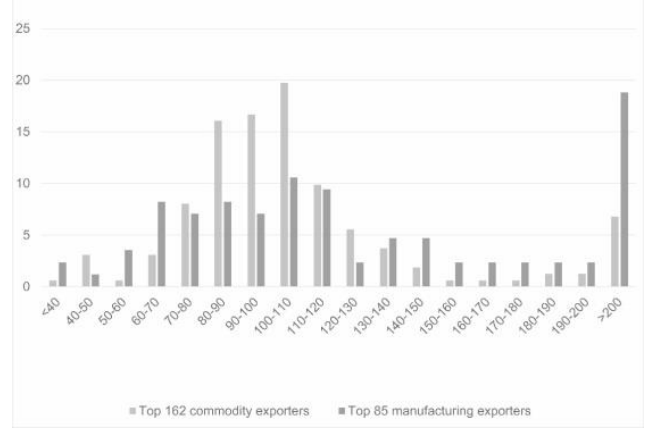

Figure 1. Leading Russian exporters: Rates of export revenue, \% change 2013-2014 (data standardized according to the number of rating participants)

Source: authors based on Expert Business Weekly (2015)

The data in Figure 1 show that in 2014, only half of resource exporters increased their revenue as compared with 2013; the share of non-resource exporters with positive revenue growth is over $60 \%$. The graph also shows that resource exporters' change in revenue was more stable and fluctuated around 100\%; the largest number of rating participants had sales growth in the foreign markets of $0-10 \%$, whereas for the exporters, the most common growth of revenue was more than three times (this also includes the cases where the companies only exported products in 2014). 


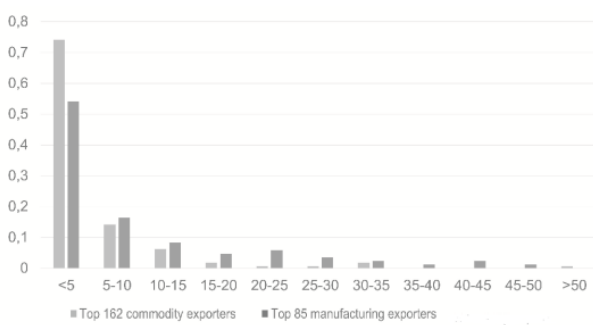

Figure 2. Leading Russian exporters: Number of HS 4-digit commodity lines exported in 2014, \% (data standardized)

Source: authors based on Expert Business Weekly (2015)

The data in Figure 2 show that both resource and non-resource exporters were characterized by low commodity diversification, with up to 5 four-digit items under CN FEA: Among the resource companies, around $74 \%$ of enterprises fell into this category, and 54\% of non-resource companies.

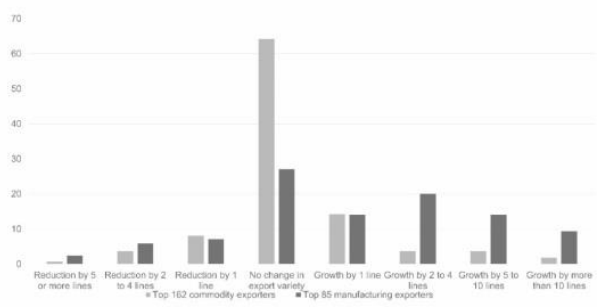

Figure 3. Leading Russian exporters: HS 4-digit commodity lines added/removed 2013-2014, \% (data standardized) Source: authors based on Expert Business Weekly (2015)

The relative frequency indicators of change in the commodity items shown in Figure 3 demonstrate that resource exporters are less inclined toward commodity diversification (the share of conservatives is close to 65\%), which is due to technological characteristics and the high level of product homogeneity, which are typical for the primary processing industries. For non-resource companies, this indicator is about $27 \%$, while the share of those that had increased the number of exported items by at least one was $57 \%$.

The data in Figure 4 show that resource companies were characterized by a higher level of geographical diversification, which is related to the universal nature of their competitive advantage due to the country's rich reserves and developed production and distribution infrastructure.

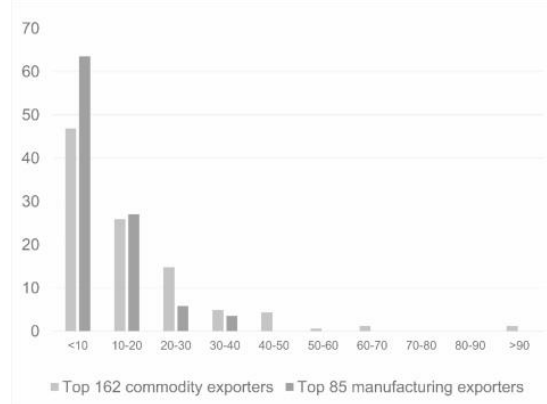

Figure 4. Leading Russian exporters: Countries served in 2014, \% (data standardized)

Source: authors based on Expert Business Weekly (2015) 
About $90 \%$ of non-resource exporters operated in fewer than 20 foreign markets, among which over $60 \%$ operated in fewer than 10 markets; this is not surprising, since exporters are most often the companies that came into being in the 1990s or subsidiaries of foreign manufacturers born in the investment boom that took place in the 2000s. Therefore, these companies, in the authors' opinion, have good prospects for further expansion due to the relatively short period of their existence and opportunities to take advantage of their location in the large and competitive Russian market. The data in Figure 5, on the whole, show that non-resource exporters were more conservative about geographical expansion than resource companies; the share of companies that did not change their number of foreign target markets is about $60 \%$. In this situation, a little more than $50 \%$ of resource exporters from the rating increased their number of trade partner companies; for the non-resource export leaders, this figure is about $26 \%$.

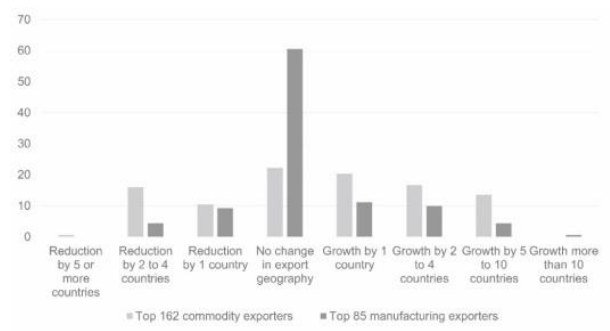

Figure 5. Leading Russian exporters: Served countries added/removed 2013-2014, \% (data standardized) Source: authors based on Expert Business Weekly (2015)

In a certain way, the data shown in Figures 3 and 5 prove to the contrary a greater inclination of resource exporters toward country (geographical) diversification, whereas the foreign trade expansion of non-resource companies implies manipulation of the number of commodity items.

Within the frame of research, the authors built a dependence between the revenue index and commodity and geographical diversification indexes for the data arrays of the 200 leading exporters (among them 162 resource exporters presented in the general rating) and 85 non-resource exporters. The results of the analysis are shown in Table 3. The actual sampling included 198 out of 200 leading exporters (no data were provided for two companies, one of which did not export in 2013); broken down by HS four-digit codes, it included and 76 and 81 of the exporters in 2013 and 2014, respectively, and broken down by countries, 77 and 82 of the 85 non-resource exporters in 2013 and 2014, respectively.

This correlation analysis identified three significant positive correlations between the export revenue indicators, on the one hand, and commodity and geographical diversification parameters, on the other hand. First, the first positive correlation regards the geographical expansion (for the general rating participants, the correlation is 0.593), which is explained, first of all, by resource exporters (the correlation ratio between the changes of export revenue and the number of target markets is 0.625 ), whose products are unique, and the price advantages are undoubted, and any additional foreign market contributes to the gross revenue growth.

Table 3. Correlation analysis results of export revenue of the top 200 Russian leading exporters and the top 85 Russian manufacturing exporters

\begin{tabular}{lccc}
\hline \multirow{2}{*}{ Indicator } & \multicolumn{2}{l}{ Period } & \\
\cline { 2 - 4 } & 2014 & 2013 & 2014 to 2013 \\
\hline Top 200 leading exporters & & & \\
\hline HS 4-digit commodity lines exported & 0.262 & 0.249 & -0.021 \\
\hline Countries served & 0.334 & 0.328 & 0.593 \\
\hline Top 162 leading commodity exporters (isolated from the top 200 list) & & \\
\hline HS 4-digit commodity lines exported & 0.425 & 0.375 & -0.024 \\
\hline Countries served & 0.341 & 0.330 & 0.625 \\
\hline Top 85 leading manufacturing exporters & & & \\
\hline HS 4-digit commodity lines exported & 0.409 & 0.620 & 0.265 \\
\hline & & & \\
\hline
\end{tabular}




\begin{tabular}{lrrr}
\hline Countries served & 0.383 & 0.421 & 0.415 \\
\hline Top 84 leading manufacturing exporters (Rosatom corporation excluded) & & \\
\hline HS 4-digit commodity lines exported & 0.284 & 0.347 & 0.264 \\
\hline Countries served & 0.184 & 0.284 & 0.415
\end{tabular}

* Correlation from 0,5 to 0,75 in italic

Source: authors' calculations based on Expert Business Weekly (2015)

Second, the non-resource (manufacturing) exporters had a significant connection between the absolute value of export revenue and the number of four-digit commodity items, which was better shown in 2013 (correlation ratio 0.620 ) than in 2014 (correlation ratio 0.409). However, the presence of such a significant connection is determined by the presence in the rating of a participant with anomalously high export volumes: Rosatom Corporation. If we exclude this participant from the assessment, this significant indicator disappears.

For the purpose of regression analysis, an additive regression model for the absolute and logarithmic values of export output (ExpOutput and LNExpOutput) considered as dependent variable and diversification parameters such as HS 4-digit commodity lines exported (ComLinesNum and LNComLinesNum) and Countries served (CountrNum and LNCountrNum) as independent (tool) variables were estimated.

ExpOutput $=\alpha_{0}+\alpha_{1}$ ComLinesNum $+\alpha_{2}$ CountrNum $+\varepsilon$

This linear regression model implies that the export output of a company is a straight-line function of each of two diversification variables HS 4-digit commodity lines exported and number of countries served. With a certain simplification, we can assume that $\alpha 1$ and $\alpha 2$ represent an absolte contribution to export output produced by a new country served or a new commodity position added to a product range.

\section{LNExpOutput $=\alpha_{0}+\alpha_{1}$ LNComLinesNum $+\alpha_{2}$ LNCountrNum $+\varepsilon$}

The regression in logarithmic values (Log-Log model) implies a cautious hypothesis that $\alpha 1$ and $\alpha 2$ show the elasticity relationship between a change in export output and a change in the considered diversification parameters.

Table 4. Regression results

\begin{tabular}{llll}
\hline & All Exporters & Commodity Exporters & Manufacturing Exporters \\
\hline Linear model & & & \\
\hline Intercept & $-1539.24^{* *}$ & $-1596.45^{*}$ & $-76.921^{* *}$ \\
\hline ComLinesNum & $167.66^{* *}$ & $480.01^{* * *}$ & $11.075^{* * *}$ \\
\hline CountrNum & $135.64^{* * *}$ & $105.63^{* *}$ & $8.253^{* * *}$ \\
\hline Adjusted R-squared & 0.1241 & 0.1743 & 0.3686 \\
\hline Log-Log model & & & $2.76328^{* * *}$ \\
\hline Intercept & $3.44075^{* * *}$ & $4.2184^{* * *}$ & $0.32314^{* * *}$ \\
\hline ComLinesNum & -0.01732 & $0.3525^{* * *}$ & $0.05484^{* * *}$ \\
\hline CountrNum & $0.80659^{* * *}$ & $0.5391^{* *}$ & 0.2801 \\
\hline Adjusted R-squared & 0.1936 & 0.2202 & 152 \\
\hline Observations & 475 & 323 & \\
\hline
\end{tabular}

Significance codes: $0 * * * 0.001 * * 0.01 *$

Both the regression models obtained indicate that the choice to analyze separately commodity and manufacturing exporters was adequate, since the explanatory power of models (adjusted R-squared) built for separate datasets of exporters exceeds the the explanatory power of the regression based on the common dataset. A relatively low overall explanatory power of all the regression equations made may be attributed to the impossibility to include other independent variables in the model due to the Expert ranking format. Nevertheless, the regression coefficients obtained for analyzed commodity and geographical diversification parameters resulted to be significant to export income characterization. 
The fact that the equations for manufacturing exporters in both the cases showed a higher explanatory power may be associated to lower dependence of their export output on price changes as it occurs for the exporter of commodities. So, the manufacturing exporters rather exporters of raw materials may rely more on their marketing and innovation decisions. The linear model showed that the addition of a new product in terms of HS 4-digit code would lead to a bigger increase in export income than a new national market entry. For the commodity exporters the contribution of an extended product range is equal to $\$ 480 \mathrm{mln}$ while for the manufacturing exporters is equal to $\$ 11 \mathrm{mln}$, the addition of a new country is worthy $\$ 105.63 \mathrm{mln}$ and $\$ 8.253 \mathrm{mln}$ respectively. The log-log model results partially supported the correlation analysis output, since the export output of manufacturers resulted more elastic in terms of product diversification, while the export ouptut of commodity producers is more elastic in terms of geographic diversification.

Apart from assessment of dependence between the revenue parameters, on the one hand, and commodity and geographical diversification indexes, on the other hand, the authors performed a correlation analysis of data broken down by the industries of the exporting enterprises from the rating. The analysis made use of data from industries with information for at least 13 enterprises. The results of correlation analysis are shown in Table 5.

Table 5. Correlation analysis results of export revenue of the top Russian leading exporters by industry with at least 10 enterprise present in the ranking

\begin{tabular}{|c|c|c|c|}
\hline \multirow{2}{*}{ Indicator } & \multicolumn{3}{|l|}{ Period } \\
\hline & 2014 & 2013 & 2014 to 2013 \\
\hline \multicolumn{4}{|c|}{ Timber, woodworking, pulp, and paper industry ( 25 companies) } \\
\hline HS 4-digit commodity lines exported & 0.433 & 0.384 & -0.073 \\
\hline Countries served & 0.394 & 0.359 & -0.102 \\
\hline \multicolumn{4}{|l|}{ Oil and gas industry (34 companies) } \\
\hline HS 4-digit commodity lines exported & 0.608 & 0.711 & -0.049 \\
\hline Countries served & $\mathbf{0 . 7 8 9}$ & 0.843 & 0.924 \\
\hline \multicolumn{4}{|l|}{ Food industry (13 companies) } \\
\hline HS 4-digit commodity lines exported & 0.425 & 0.613 & 0.158 \\
\hline Countries served & 0.741 & 0.704 & 0.776 \\
\hline \multicolumn{4}{|l|}{ Coal industry (18 companies) } \\
\hline HS 4-digit commodity lines exported & 0.658 & 0.620 & 0.061 \\
\hline Countries served & 0.704 & 0.693 & 0.731 \\
\hline \multicolumn{4}{|c|}{ Chemical and petrochemical industry (24 companies) } \\
\hline HS 4-digit commodity lines exported & 0.357 & 0.552 & -0.047 \\
\hline Countries served & 0.531 & 0.604 & 0.126 \\
\hline \multicolumn{4}{|l|}{ Metallurgy (31 companies) } \\
\hline HS 4-digit commodity lines exported & 0.490 & 0.427 & -0.034 \\
\hline Countries served & 0.359 & 0.335 & 0.073 \\
\hline \multicolumn{4}{|c|}{ Machinery manufacturing industry (50 companies) } \\
\hline HS 4-digit commodity lines exported & 0.387 & 0.619 & 0.259 \\
\hline Countries served & 0.507 & 0.539 & 0.552 \\
\hline \multicolumn{4}{|c|}{ Machinery manufacturing industry (46 companies, 4 leaders excluded) } \\
\hline HS 4-digit commodity lines exported & 0.575 & 0.429 & 0.251 \\
\hline Countries served & 0.442 & 0.437 & 0.563 \\
\hline
\end{tabular}

* Correlation from 0,5 to 0,75 in italic

** Correlation more than 0,75 in bold

Source: calculations made by the authors 
The seven industry groups analyzed-(1) wood, wood processing, and pulp-and-paper industry; (2) oil and gas industry; (3) food industry; (4) coal industry; (5) chemical and petrochemical industry; (6) metallurgy; and (7) machinery manufacturing industry - may be broken down into three subgroups based on the results of the correlation analysis. First, the industries demonstrating an obvious correlation between the export volume and both the HS four-digit commodity lines and the number of countries served are the oil and gas industries and the coal industry (monoproduct industries). Second, the industries not demonstrating an obvious correlation between the export volume and the HS four-digit commodity lines but demonstrating a correlation between the revenue and the countries served are the food industry and the chemical and petrochemical industries; they are characterized by relatively diverse exports, with 6 or 7 HS four-digit commodity lines. Third, the industries not demonstrating a visible dependence of export volume on both the HS four-digit commodity lines and the countries served are the wood, wood processing, and pulp-and-paper industries as well as metallurgy (ferrous and non-ferrous metallurgy).

The position of the machinery engineering industry in the classification provided is determined by whether its leaders are taken into account or not; hence, if we leave the four industrial leaders-Rosatom Corporation, United Engine Corporation, Tactical Missiles Corporation, and Rosoboronexport (Russian Defense Export Corporation) - in the calculations, this industry can be added to the second group; if we exclude them, to the third group.

\section{Conclusion}

Exports play a key role in the general system of the country's competitiveness. At the macro-level, a positive trade balance sets the stage for a stable for a stable monetary system and national currency; at the meso-level - industry-wise and region-wise - it maintains the employment and stability of the production system and investments; for enterprises, exports are most often a sign of high competitive potential, which makes it possible to enjoy a stable position in the domestic and foreign markets, which is important in the era of globalization.

Nowadays, global trade is undergoing an unfavorable period: foreign trade turnover is shrinking in many countries of the globe due to a global recession and the absence of growth drivers in both developed and developing countries.

Research on the number of foreign trade indicators of the leading Russian resource and non-resource exporters was performed through the lens of the theory of heterogeneous exporters due to the introduction into the scientific discourse of data of ratings by Expert Business Weekly (2015) of the 200 leading exporters and 85 leading non-resource exporters of Russia.

The results of the research yielded high volatility of the proceeds from exports for the companies reviewed, which is most typical for the non-resource exporters. The research revealed significant differences in diversification between commodity producers and manufacturers: the commodity diversification and inclination to change it of manufacturing exporters are higher than those of commodity exporters, while the situation is opposite as regards geographical diversification. Correlation analysis also yielded a significant coupling between revenue growth and geographical diversification based on the sampling of 200 leading exporters (this indicator is due to the resource exporters).

The regression models obtained although their simplicity indicated a acceptability of separate modeling of commodity and manufacturing exporters performance. Their relatively low explanatory power can be attributed to the impossibility to include other independent variables, notwithstanding the considered commodity and geographical diversification parameters resulted to be significant to export income characterization. The linear models obtained for both the groups of exporters showed that the addition of a new product in terms of HS 4-digit code would lead to a bigger increase in export income than a new national market entry. It is a result of the fact that the geographical diversification is more explicit for both the exporter types.

Analysis of industry indicator correlation identified that the export revenues of monoproduct industries (fuel exporters) - oil-and-gas and coal industries - are positively related to both the number of HS 4-digit commodity lines and the number of trade partner countries, whereas the export revenues of exporters belonging to the chemical, petrochemical, and food industries, which are comparatively diverse as regards trade diversification, are related to the number of countries served.

Therefore, the results obtained make it possible to give recommendations of an applied nature to resource and non-resource exporters and export-supporting authorities at the regional and federal levels. So, the authorities should support a product diversification of exporters. In general terms they may promote the innovation and renewal of product line. Concerning the export support specific tools, the government through official foreign trade representatives may assist to negotiations aimed to a new market entrance of commodity exporters. For the 
manufacturing exporters the compensation of international marketing expenditures such as exhibition fees or brand registration overseas cost may be relevant as it happens now may be efficient.

\section{References}

Andreeva, E. L., Sobolev, A. O., \& Ratner, A. V. (2017). Foreign trade relations of the Sverdlovsk region and their prospects, taking into account new guidelines for the development of non-primary exports. Russian Foreign Trade Bulletin, 2, 55-70.

Bernard, A. B., \& Jensen, J. B. (1999). Exceptional exporter performance: Cause, effect, or both?. Journal of International Economics, 47(1), 1-25. https://doi.org/10.1016/S0022-1996(98)00027-0

Bernard, A. B., Jensen, J. B., Redding, S. J., \& Schott, P. K. (2007). Firms in international trade. Journal of Economic Perspectives, 21(3), 105-130. https://doi.org/10.1257/jep.21.3.105

Boehe, D. M., \& Jiménez, A. (2016). How does the geographic export diversification-performance relationship vary at different levels of export intensity?. International Business Review, 25(6), 1262-1272. https://doi.org/10.1016/j.ibusrev.2016.03.011

Eaton, J., Kortum, S., \& Kramarz, F. (2011). An anatomy of international trade: Evidence from French firms. Econometrica, 79(5), 1453-1498. https://doi.org/10.3982/ECTA8318

Evchenko, N. N., \& Gubanov, V. P. (2013). Diversification of exports of Russian regions: the trend of monoproductivity growth. South Russian Forum: Economics, Sociology, Political Science, Socio-Economic Geography, 1(6), 68-75.

Expert Business Weekly. (2015). Wake up and be an exporter. Expert Business Weekly, 13, 15.

Gnidchenko, A. A. (2014). Improvement of methods for assessing the structure and base of export potential through export diversification. Journal of the New Economic Association, 1(21), 83-109.

Government of the Russian Federation. (2008). The external economic strategy of the Russian Federation until 2020 (approved by the Government of the Russian Federation in 2008). Retrieved from http://economy.gov.ru/minec/activity/sections/foreignEconomicActivity/vec2020

Hennart, J.-F. (2007). The theoretical rationale for a multinationality-performance relationship. Management International Review, 47(3), 423-452. https://doi.org/10.1007/s11575-007-0023-3

Kat'kalo, V. S., \& Medvedev, A. G. (2011). Internationalization of Russian companies and the configuration of their business operations. Bulletin of the St. Petersburg State University. Series 8, Management, 2, 7-38.

Kuznetsov, A. (2010). Urgent tasks for research on Russian TNCs. Transnational Corporations, 19(3), 81-95. https://doi.org/10.18356/a4d8cef8-en

Kuznetsov, A. (2011). The development of Russian multinational corporations. International Studies of Management and Organization, 41(4), 34-50. https://doi.org/10.2753/IMO0020-8825410402

Kuznetsov, A. V. (2016). Study of transnational corporations in IMEMO: achievements and new tasks. World Economy and International Relations, 60(12), 111-117. https://doi.org/10.20542/0131-2227-2016-60-12-111-117

Kuznetsov, A. V. (2017). Prospects for diversifying Russian direct investment abroad. Studies on Russian Economic Development, 1, 103-113. https://doi.org/10.1134/S1075700717010075

Lawless, M., Siedschlag, I., \& Studnicka, Z. (2018). Firm strategies in expanding and diversifying exports. The World Economy, 42(2), 1-25. https://doi.org/10.1111/twec.12702

Medvedev, D. A. (2018). The main activities of the Government until 2024. Video Blog of the Chairman of the Government of the Russian Federation D.A. Medvedev. Retrieved from http://government.ru/news/34153/

Panibratov, A. (2010). Russian multinationals: Entry strategies and post-entry operations. Electronic Publications of $\begin{array}{llll}\text { Pan-European } & \text { Institute, } & 15 . & \text { Retrieved }\end{array}$ http://www.utu.fi/fi/yksikot/tse/yksikot/PEI/raportit-ja-tietopaketit/Documents/Panibratov_netti_final.pdf

Panibratov, A. (2012). Russian multinationals: From regional supremacy to global lead. Routledge. https://doi.org/10.4324/9780203130377 
Panibratov, A. Ju., Veselova, A. S., \& Ermolaeva, L. A. (2015). Institutional and macroeconomic factors of the geographical direction of Russian international mergers and acquisitions. Russian Management Journal, 13(3), 59-78.

Piskulova, N. A. (2015). Modern trends and features of the development of Russian foreign trade. MGIMO Journal, 6(45), 225-235.

Shurygin, Ju. (2017). Wild failure and great opportunities. Expert Business Weekly, 3, 32-37.

Spartak, A. N., \& Hohlov, A. V. (2016). Russian exports in 2015: stagnation or progress?. Russian Foreign Trade Bulletin, 3, 3-12.

Yudanov, A. Ju. (2010). Conquerors of the "blue oceans" (firms - "gazelles" in Russia). Contemporary Competition, 2(20), 27-28.

Yudanov, A. Ju. (2013). On the formula for the success of medium-sized businesses in the world and in Russia. Russian Management Journal, 11(3), 119-128.

Zhoga, G. (2015). Special report "Russian exports" - how to deceive the conjuncture. Expert Business Weekly, 40. Retrieved

from http://expert.ru/expert/2015/40/spetsialnyij-doklad--rossijskij-eksport-kak-obmanut-kon_yunkturu/

\section{Copyrights}

Copyright for this article is retained by the author(s), with first publication rights granted to the journal.

This is an open-access article distributed under the terms and conditions of the Creative Commons Attribution license (http://creativecommons.org/licenses/by/4.0/). 